\title{
International acquisitions and shareholder wealth Evidence from the Netherlands
}

\author{
$\operatorname{CorhayA}^{[1]}$, Tourani $\operatorname{Rad} \mathrm{A}^{[2]}$ \\ ${ }^{[1]}$ University of Liege and Maastricht University, Department of Finance, Boulevard du Rectorat, 7 \\ (B31), \\ 4000 Liège, Belgium ${ }^{[2]}$ University of Waikato, School of Management Studies, Department of Finance, \\ Private Bag 3105, Hamilton, New Zealand
}

\begin{abstract}
In this article, we test wealth effects of international acquisitions using a sample of foreign acquisitions by Dutch firms during the period 1990-96. We find weak evidence that cross-border acquisitions are wealth-creating corporate activities, especially for acquisitions in the U.S. We observe further that for the West European acquisitions, benefits from internalization are larger for companies having relatively less international exposure and making acquisitions outside of their main activities.
\end{abstract}

\section{Keywords}

Corporate control, Mergers, Acquisitions, International finance

\section{Introduction}

In The Netherlands, because of the long history of an open economy and the strong international orientation of firms, cross-border transactions have been quite widespread. For instance, for the period from 1985 to $1995,1,598$ out of a total of 2,505 mergers and corporate restructuring transactions were cross-border transactions. In 839 cases (53\%), a Dutch company acted as buyer of a foreign company. The majority of acquisitions have taken place in Germany, Belgium, the United Kingdom, and the United States.

Several theories can explain the rapid growth of cross-border acquisitions by the Dutch firms during the past decade. According to theories of foreign direct investments,

which are also related to the internalizing theory, imperfections in factor, product and capital market are the principal motives for international investments (Caves, 1971; Hymer, 1976; Errunza and Senbet, 1981). Dutch firms may decide to invest abroad to take advantage of the mispriced factors of production, cope with trade barriers, especially in the East European and former Soviet Union countries that have been opening up during the past decade. One motive for acquisitions, in Europe, is the fact that the process of unification has brought along a change in the competitive environment among firms. Due to this process, a wave of concentrations through domestic and cross-border acquisitions has been taking place. It is important for Dutch firms to obtain a pan-European or insider status when political and economic unification in Europe (and especially the introduction of Euro) make such status important.

Strategic motives for international acquisitions, applicable mainly for larger Dutch firms, contend that firms enter into foreign markets, especially those of their global competitors, giving them options to seize new niches or limiting profits of competitors that have already seized such niches (Hill et al., 1991).

Management-driven motives to pursue growth and diversification can play also a role in international acquisitions by Dutch firms. Cross-border acquisitions minimize the risk because firms are no longer relying on a single economy. The diversification motive is based on the fact that corporate earnings are likely to be less correlated across countries than within a single country because of, for instance, nonsynchronous business cycles. Thus, acquiring a foreign, rather than a domestic firm, can more effectively reduce the corporate earnings variability and can provide indirect international portfolio diversification to the shareholders. The latter is true only if barriers to international capital flows prevent the investors from diversifying on their own (Errunza, 1977; Lessard, 1976; Lougue, 1982). Growth and diversification can also be a motive for international acquisitions when the Dutch economy faces dim growth prospects or when there may be no suitable acquisition candidates in the home 
market.

Exchange rate differences between a foreign country and the Netherlands may also encourage firms to acquire internationally, i.e., acquiring foreign firms can be cheaper when the Dutch guilder is strong relative to other currencies (Froot and Stein, 1989). Moreover, Dutch firms can also takeover other firms abroad to localize revenues and costs to diminish the impact of foreign exchange movements. Finally, the lack of corporate control transactions at home can be a major rationale for Dutch firms looking for growth and diversification to engage in international takeovers. We will elaborate more on this issue in a later section discussing corporate governance in the Netherlands.

The available empirical research on cross-border mergers and acquisitions has been dominated by the research carried out mainly in the U.S. Whether cross-border acquisitions create value for the firms undertaking such transactions is thus far from settled. The question of wealth effect in cross-border acquisitions for acquiring firms requires additional investigation, especially in countries having different legal and institutional settings. This is the main objective of this article: We investigate the wealth effects on acquiring Dutch firms involved in cross-border acquisitions. The rest of the paper is organized as follows. The section 2 gives an overview of the related

studies. Then the peculiarities of the Dutch corporate governance system are studied in section 3. In the sections 4-6, hypotheses, methodology, and data are presented. Section 7 contains the empirical findings. The final section concludes the paper.

\section{Related studies}

A number of studies have examined the wealth impact of shareholders involved in cross-border acquisitions. Doukas and Travlos (1988) examined shareholder value creation of 301 cross-border acquisitions undertaken by U.S. firms for the period from 1975 to 1983 . They subdivided their sample into firms that were already present in the country of the acquired company, firms that were not operating in the target country, and finally firms going abroad for the first time. They found announcements of acquisitions by companies in the first and the third subsamples caused zero or insignificant fall in their returns. Yet, the result for the subgroup "not operating in the target firms' country" was, on average, positive and statistically significant. This was particularly the case when firms expanded into a new industry and/or a new country. Doukas and Travlos argued that their findings support the positive multinational network theory, according to which the positive wealth effect of international acquisitions reflects the systemic opportunities that stem from the expansion of present activities of multinational companies.

Fatemi and Furtado (1988) looked at a sample of 117 U.S. bidding firms for the period from 1974 to 1979. They found negligible abnormal returns. Conn and Connell (1990) examined a sample of international mergers involving U.S. and U.K. firms from 1971 to 1980 and reported abnormal returns of about $2 \%$ for the bidding firms. They found positive abnormal returns of acquired companies in the U.K. to be half that of their U.S. counterparts. Markides and Ittner (1994) examined the impact of international acquisitions made in the period from 1975 to 1988 on the market value of the U.S. bidding firms. They reported a 2-day abnormal return of $0.32 \%$, which was significant only at the $10 \%$ level. They argued that, "The stock market, therefore, is not overly enthusiastic about international acquisitions. It does not view them, however, as good news." They further observed that acquisitions in related industries created more value than those in unrelated industries. Datta and Puia (1995) investigated the effect on shareholders' wealth of 112 international acquisitions undertaken by U.S. firms for the period from 1978 to 1990. They observed that cross-border acquisitions, on average, destroy value for shareholders of U.S. bidding firms. Kang (1993) studied 102 Japanese acquisitions of U.S. firms between 1975 and 1988. He concluded that these transactions created significant wealth gains for bidding firms and observed a positive correlation between the appreciation of the yen and the gains to Japanese shareholders.

This overview illustrates that there are no clear empirical results confirming the wealth creation for the shareholders of bidding firms due to international takeovers.

\section{Corporate governance system in the Netherlands}

An international comparison among countries shows strong differences among corporate ownership structures and the effectiveness of the market for corporate control, which are the major constituents of the corporate governance systems. Corporate governance systems can generally be divided up into market-based systems and network-based systems (Prowse, 1995). 
Market-based systems can be characterized by well-developed financial markets, the large scale presence of public corporations with widely dispersed share-ownership, active markets for corporate control, and low levels of corporate equity ownership by banks. The market-oriented systems can be found in the English-speaking countries, like the United States, the United Kingdom, Canada, and Australia.

Network-based systems can be characterized by a large number of privately held corporations, group membership of corporations, extensive involvement of banks in financing and controlling firms, and concentrated equity ownership. In such systems, the market for corporate control is virtually nonexistent. Corporate equity is in the hands of large shareholders, and through their concentrated holdings, they are able to influence management directly, not via the market for corporate control. Substantial blocks of equity held by large investors function also as major barriers to hostile takeovers. The network-oriented system can be found in many Continental European countries and in Japan. Regarding the Dutch system, it could be argued that while the network-based system prevails, some characteristics of the market-based system can also be distinguished. The stock market in the Netherlands is relatively well developed, which may be considered a common feature of the marketoriented system. The ownership structure is rather dispersed: individuals 19\%, private companies $19 \%$, foreign investors $37 \%$, institutional investors $22 \%$, and banks $2 \%$. These figures, which are for 1995 , reveal a situation rather closer to the U.S. than for other continental European countries. It is interesting to note the large amount of shares held by foreigners, reflecting the open structure of the Dutch economy. The small percentage of shares held by banks, $2 \%$, is also comparable with the AngloAmerican situation. This can be partly explained by the regulation of equity holdings for banks. When a Dutch bank takes a participation of over $10 \%$ in a corporation, approval by the Dutch Ministry of Finance is required. In reality, the reason is that the focus of the Dutch banking system is trade finance and not long-term industry finance, such as is the case in Germany.

The governance structure of Dutch firms has two tiers: supervisory and executive boards. The supervisory board is composed of outside experts like bankers, retired politicians, and corporate executives of other firms. The supervisory board monitors the executive board, which consists of the top management of the firm. In the Netherlands, the supervisory board is legally obliged to guard the firm as a whole, not only the interests of a particular stakeholder. The supervisory board, thus, has a broader control function than the boards of directors in the Anglo-American countries, which are concerned with the primary interests of shareholders. A unique characteristic of the Dutch system is the fact that the members of the supervisory board are appointed by co-option. This means that existing members choose new members and not the shareholders. There is no room for proxy fights in the Netherlands as there is no chance of removing the existing members of the supervisory team. The market for corporate control is virtually absent, which may be considered as a feature of the network-oriented system. This is because most Dutch-listed companies have adopted severe takeover defenses. The most common ones are: priority shares, which gives holders special rights to change the articles of association; certificate shares, which separate the voting rights from financial rights; preference shares, which are the same as poison pills; and voting caps, which place a limit on the amount of voting rights by any shareholder.

\section{Hypotheses}

To determine whether international acquisitions undertaken by the Dutch firms increase the shareholders' wealth, several hypotheses are developed. The first hypothesis is the wealth hypothesis: international mergers create value for the shareholders of the bidding firms. This hypothesis is tested for three subgroups: Western Europe, Eastern Europe, and the U.S. The argument behind this geographical partitioning is as follows. The corporate objectives, managerial views, and norms differ substantially in Europe from those in the U.S. For instance, Grey and Thorne (1990) report that European firms are more likely to be oriented toward long-term goals, have specified plans to meet these goals, and are more responsive to changes in corporate environment. Most Western European countries still have different legal and institutional regulations that stand in the way of a truly free market for corporate control. This implies a weaker competition in European markets for corporate control and less merger and acquisition activities. Even though Western Europe cannot yet be considered as a truly single market, the differences in European markets are being reduced by the introduction of European Union Directives (e.g., in mergers and takeovers). For these reasons, we consider Western Europe to form a single subgroup. We know little about Eastern European markets for corporate control and merger and acquisition activities. Given the recent shift from a planned to a market economy and the important political and legal changes that are taking place in this region, we 
can hardly speak of any proper functioning of markets for corporate control. Yet, East Europe is becoming more and more attractive for Western companies and the functioning of the takeover market there is worth investigating. Finally, we look at acquisitions in the U.S. market separately.

We further attempt to explain the variations in cross-sectional wealth effects of foreign acquisitions in the Netherlands. We concentrate on three variables, namely the relative size of the target company to the bidding company, the extent of foreign exposure of the bidding company, and finally if the takeover is in a related industry or not.

- The second hypothesis is the size hypothesis: cross-border acquisitions create more value when the size of the target firm is large relative to that of the acquiring firm.

- The third hypothesis is the relatedness hypothesis: cross-border acquisitions create more value when the acquiring and the target firms are in the same line of business.

- The fourth hypothesis is the international exposure hypothesis: cross-border acquisitions involving firms with high level of foreign exposure should create less value.

It has to be noted that other factors like changes in exchange rate or in taxes, which have been extensively examined in other studies, are not of importance during our investigation period for the Dutch market. The Dutch guilder had been rather stable during this period, and there was no change in the tax system. Moreover, the method of payment has been mainly in the form of cash.

\section{Methodology}

This study uses the event study methodology with daily data and the market model. The coefficients of the market model are estimated using 200 returns for the period of 240 days to 41 days before the announcement day. A period of 40 days before and 40 days after the announcement day is used as the investigation period. Abnormal Returns (AR) during this period are the actual returns minus the predicted returns based on the market model:

$$
A R_{i t}=R_{i t}-\left(\alpha_{i}+\beta_{i} \times R_{m i}\right)
$$

where $R_{m t}$ represents the return on the market on day $t, R_{i t}$ stands for the return of stock $i$ on day $t$, corrected for dividends, and $\boldsymbol{\alpha}_{i}$ and $\boldsymbol{\beta}_{i}$ are the market model parameters estimated for stock $i$. The Cumulative Abnormal Returns (CAR) are then calculated over several subperiods to measure the impact of the merger announcement in these periods.

To determine the statistical significance of the results, $t$ values for each of the AR and CAR are calculated. The $t$ statistic for the CAR is defined as follows:

$$
t_{C A R_{: P}}=\frac{C A R_{i P}}{\sqrt{p_{2}-p_{1}+1} \times \hat{s}(e)}
$$

where

$$
\hat{s}(e)=\sum_{t--24 i}^{-41} \sqrt{\frac{\left(e_{i}-\overline{e_{i}}\right)^{2}}{200}}, \bar{e}_{i}=\sum_{i--240}^{-41} \frac{e_{i t}}{200}, p_{1}\left(p_{2}\right)
$$

is the starting (ending) day of the cumulative period and $e_{i}$ is the estimation error during the estimation period.

\section{Sample and data}

Our analysis concerns non-financial Dutch firms that carried out a cross-border acquisition in the period from January 1, 1990 to December 31, 1996. The data are collected from the Financieele Dagblad, a Dutch financial newspaper. The date of the first official announcement of a takeover decision is taken as the announcement date. In a number of cases the Financieele Dagblad, however, has already published rumors beforehand. In such cases, the announcement date chosen is the day when the concerned management no longer denied the rumor.

To be included in the sample, the firm's acquired interest in target companies has to exceed $50 \%$ of the outstanding shares, resulting in an effective control of the target. Furthermore, sample firms must have daily share prices available 280 days before and 40 days after the announcement day. In the Netherlands, several large firms are involved in takeover activities frequently. In the case of multiple acquisitions during the test period, only the first acquisition is considered. The final sample consists of 84 Western European, 17 American, and 10 Eastern European takeovers. 
Stock prices as well as dividends both in Dutch guilders are collected from Datas-tream International, a U.K.-based data service company. The CBS reinvestment index, the most appropriate Dutch index available for the period under investigation, is used as the market index. Returns are calculated as the difference in natural logarithm of two consecutive daily stock prices, taking dividend payments into account.

Data on the annual sales figures and industrial classification for both the target and the acquirer and the foreign sales figure of acquiring firms are also collected.

\subsection{Proxies}

\subsubsection{Size}

The annual sales figure for both bidding and target firms is used as proxy for their size. If the ratio of target's sales to the bidding firm's sales is larger than or equal to $10 \%$, a takeover is considered to be large and the dummy variable SIZE is set to 1 ; otherwise it is 0 .

\subsubsection{Relatedness}

The industry relatedness is based on the first two digits of the Dutch SIC code and the information from the review "Mergers and Acquisitions in the Netherlands" produced by the consulting firm Price Waterhouse. Industries are classified as being related when their SIC codes match and unrelated otherwise. The dummy variable INDUSTRY is set to 1 when the industries are related and to 0 when unrelated.

\subsubsection{Foreign exposure}

The foreign exposure is measured as the ratio of foreign sales to total sales of the acquiring company. This variable gives an indication as to the extent the company has already been active in the international markets. The dummy variable FOREIGN is set equal to 1 when the foreign sales percentage is higher than or equal to $40 \%$ and to 0 otherwise. In other studies, the foreign exposure is calculated by firms having operations in a foreign country or not, or going abroad for the first time. In the case of Dutch market, it is quite difficult to find out when the firms went international for the first time. As mentioned earlier, Dutch firms are internationally oriented and a majority of them have foreign exposure. We feel our measure of $40 \%$ reflects a reasonable distinction between firms with respect to their international exposure.

It is only in the case of the European acquisitions that regressions estimating relative size, industry relatedness, and foreign exposure of the acquired company can be carried out to see if these variables play a significant role in the explanation of excess returns.

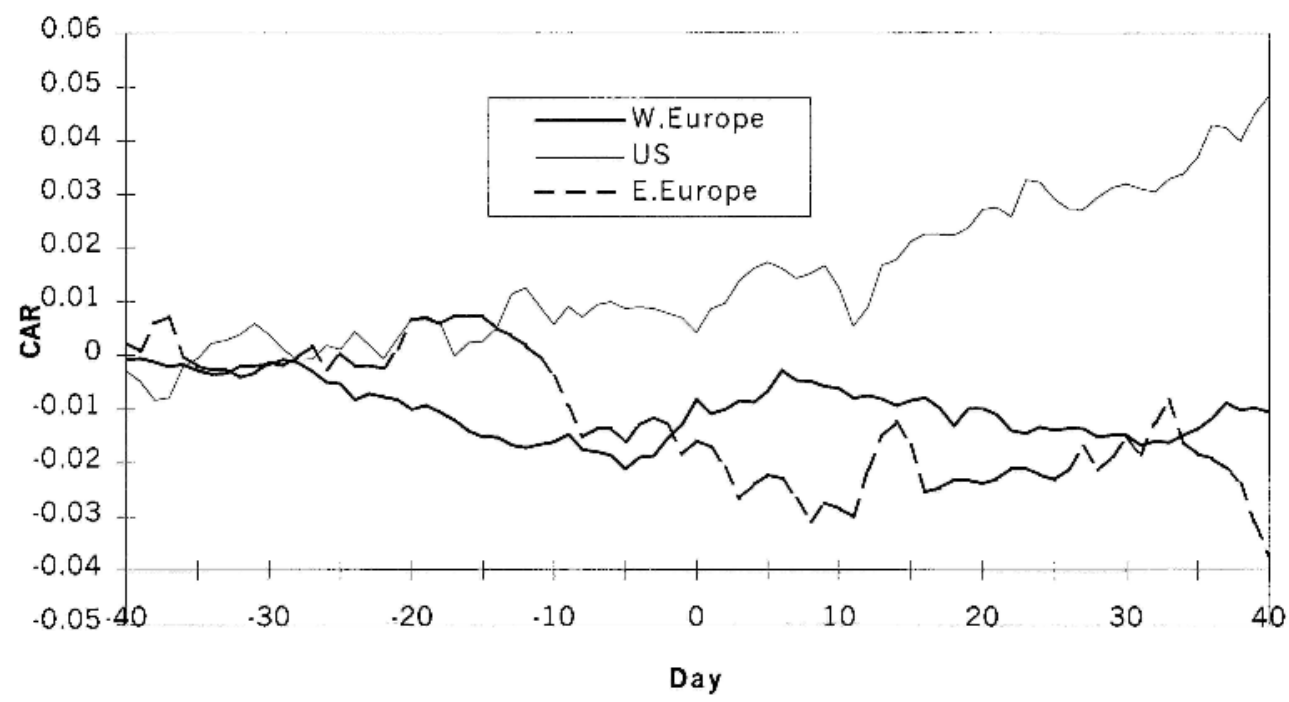


Fig. 1. Cumulative abnormal returns to Dutch shareholders from takeovers in Western Europe, the U.S., and Eastern Europe for the period from 1990 to 1996.

The same analysis cannot be carried out for the U.S. and the Eastern European subsamples. In the case of U.S. acquisitions, all the Dutch firms have indeed simultaneously large foreign exposure and all the acquisitions are in a related industry. Therefore, it is not possible to perform regression analysis due to multi-colinearity problems. The Eastern European subsample contains only 10 acquisitions, and no reliable results could be expected.

\section{Empirical results and discussions}

The average Abnormal Returns (AR) and the Cumulative Abnormal Returns (CAR) for the three subsamples are calculated. Fig. 1 depicts the CARs for the 40-day period before and after the announcement days for the three subsamples of takeover announcements. Table $1 \mathrm{~A}, \mathrm{~B}$, and C report the CARs for different intervals for Western European, U.S., and Eastern European samples, respectively. During the investigation period, the cumulative abnormal return is negative (1.05\%) but not statistically significantly different from zero for the Western European acquisitions. This is in sharp contrast to the CARs close to the announcement day, which show a clear upward trend. For example, for a 5 -day period $(-5,+5)$ surrounding the announcement day, the abnormal return is $1.44 \%$ and on the announcement day, the average abnormal return is $0.48 \%$ both statistically significant at the $5 \%$ level. It appears that West European acquisitions do positively influence shareholders' wealth during the few days surrounding the announcement day but do not have a dominant effect over a longer period.

The CAR for the U.S. acquisitions, as opposed to the CAR for Western European acquisitions, is positive for the entire period of investigation $(4.83 \%)$ and is statistically significant at the $5 \%$ level.

Table 1 CARs and their corresponding $t$ values

\begin{tabular}{lcc}
\hline Interval & CAR & t-value \\
\hline A. 84 European acquisitions by Dutch firms for various periods around the announcement days \\
\hline$(-40,40)$ & -1.05 & -1.10 \\
$(-20,20)$ & -0.33 & -0.48 \\
$(-10,10)$ & 0.91 & 0.97 \\
$(-5,5)$ & 1.44 & 1.89 \\
$(-5,-1)$ & 0.57 & 1.41 \\
$(-5,0)$ & 1.05 & $2.47 *$ \\
$(0,5)$ & 0.62 & 1.26 \\
$(1,5)$ & 0.14 & 0.09
\end{tabular}

B. 17 U.S. acquisitions by Dutch firms for various periods around the announcement days

\begin{tabular}{lll}
\hline$(-40,40)$ & 4.83 & $1.97 *$ \\
$(-20,20)$ & 2.40 & 1.27 \\
$(-10,10)$ & 0.68 & 0.42 \\
$(-5,5)$ & 0.68 & 0.85 \\
$(-5,-1)$ & -0.24 & -0.18 \\
$(-5,0)$ & -0.52 & -0.71 \\
$(0,5)$ & 0.16 & 1.31 \\
$(1,5)$ & 0.25 & $2.04^{*}$
\end{tabular}

C. 10 East European acquisitions by Dutch firms for various periods around the announcement days

\begin{tabular}{lll}
$(-40,40)$ & -3.74 & -1.27 \\
$(-20,20)$ & -1.24 & -0.83 \\
$(-10,10)$ & -1.51 & -1.62 \\
$(-5,5)$ & -0.87 & -0.84 \\
$(-5,-1)$ & -0.49 & -0.18 \\
$(-5,0)$ & -0.23 & -0.34 \\
$(0,5)$ & -0.38 & -0.83 \\
$(1,5)$ & -0.64 & -1.33 \\
\hline
\end{tabular}


The CARs for other intervals as reported in Table 1B are generally positive, except around the announcement period. On the announcement day, the average abnormal return is negative $(0.27 \%)$ but not statistically significant. It can be concluded that as far as the U.S. acquisitions are concerned, the Dutch market reacts positively.

The CARs for the sample of acquisitions in Eastern Europe over the entire period is negative (3.74\%). The average abnormal return on the day of announcement is $0.25 \%$, which is not statistically significant. The CAR for other intervals are reported in Table 1C. However, they are not statistically significant, probably because of the small number of observations in this category. These results therefore be should be interpreted with some caution.

Fatemi and Furado (1988) and Ittner and Markides (1994) argue that the nature of the market for corporate control in the target home country has an impact on the value creation of the cross-border acquisition.

Table 2 Regression analyses of Dutch acquiring firm cumulative abnormal returns for periods 1 and 10 days before announcement to 1 and 10 days after

\begin{tabular}{lll}
\hline & CAR $(-1,1)$ & CAR(-10,10) \\
\hline Intercept & 2.396 & 6.154 \\
FOREIGN & $(2.84)^{*}$ & $(3.00)^{*}$ \\
& -1.522 & -3.789 \\
INDUSTRY & $(-2.08)^{*}$ & $(-2.12)^{*}$ \\
SIZE & -1.427 & -2.727 \\
& $(-2.252)^{*}$ & $(-1.767)^{* *}$ \\
$F$ stat. & 0.865 & -0.572 \\
$R^{2}$-adj.(\%) & $(\mathrm{t} .359)$ & $(-0.369)$ \\
\hline statistics & 4.12 & 2.53 \\
& 10.28 & 5.24
\end{tabular}

t statistics in parentheses; ** Significant at 10\% level; * Significant at $5 \%$ level.

They reason that for international acquisitions to increase the shareholders' wealth, the acquisition should not only be associated with net benefits, but the market for corporate control in the target's home country must be less than perfectly competitive. The underlying rationale, which is similar to domestic acquisitions (Bradley et al., 1988; Comment and Jarrell, 1987), is that if the market for corporate control in the target country is competitive, the net benefits for the acquiring company could vanish in a bidding auction for the target company. Our empirical findings are in contrast to those of the prior studies. We find that when Dutch firms are involved in a takeover in the U.S., where the market for the corporate control is very active and much more open than the continental European markets, the shareholders gain. Our results are more consistent with those of Conn and Connell (1990), who compared international acquisitions in the U.S. and the U.K. They found positive abnormal returns of acquired companies in the U.K. to be half that of their U.S. counterparts. This, according to the authors, is because the U.K. market for corporate control is less competitive than the U.S. because of the greater agency costs and fewer regulatory and disclosure requirements. This line of reasoning can be extended to Continental European markets where the market for corporate control is ineffective and the resulting agency costs are higher. As European firms are highly protected and as a hostile takeover of them is rather impossible, it can be argued that the Dutch bidding firms have to transfer all the gainsof merger transactions to the target companies to make them agree to go ahead with the deal.

\subsection{Cross-sectional wealth effects for European takeovers}

To explain the variations in cross-sectional wealth effects of foreign acquisitions in the Netherlands, we analyze three variables: the relative size, the extent of foreign exposure, and relatedness. Regression results are reported in Table 2 for two intervals: 1 day before to 1 day after announcement, and 10 days before to 10 days after announcement. As the results are to a large extent comparable, we discuss only the shorter intervals. The intercept, showing the average CARs in the case of all dummy variables 
being equal to zero, is $2.4 \%$ and statistically significant. The Foreign dummy variable, representing the internationalization degree of the company, has a coefficient of $-1.5 \%$ and is significant. As expected, the sign of this variable is negative, indicating that the market attaches less value to international acquisitions when the company involved is highly active in the international environment. This finding is similar to Cakici et al. (1996), who found also that the extent of overseas exposure is negatively related to shareholders' wealth. Doukas (1995) also found a negative relationship where the bidder has ongoing operations in the target countries. The INDUSTRY dummy has a value of $-1.43 \%$ and is statistically significant. The sign of this coefficient is opposite to what was expected. It was thought that the opportunity for synergies would be smaller when a company invests in a non-related industry. It appears that the diversification effects of going into an unrelated business dominate the synergy effects of staying within the same industry. The coefficient of the SIZE dummy variable is 0.87 and is insignificant. It appears that the size of the target company does not have an impact on the magnitude of wealth creation.

\section{Conclusion}

Given the strong international orientation of Dutch firms and the continuous integration of the European and global markets, we expect the increasing number of cross-border acquisitions and investments in recent years to continue in the coming years. In this article, we investigated the effects of foreign acquisitions by Dutch firms on the wealth of their shareholders. We find weak evidence that cross-border acquisitions are generally wealth-creating corporate activities. The CAR for the sample of Western European acquisitions is $1.44 \%$ for a 5 -day period $(-5,+5)$ surrounding the announcement day. However, over longer periods we do not find statistically significant returns. Regarding the sample of U.S. acquisitions, while the CAR $(-40,+40)$ is $4.5 \%$ and is statistically significant, there are no favorable immediate effects around the announcement date. The results for the Eastern European sample are highly negative, but not statistically significant. We observe further that for the Western European acquisitions, benefits from internalization are larger for companies having relatively less international exposure and making acquisitions outside of their main activities.

\section{References}

Bradley, M., Desai, A, \& Kim, E. H. (1988). Synergistic gains from corporate acquisitions and their division between the stockholders of target and acquiring firms. Journal of Financial Economics 21, 340.

Cakici, N., Hessel, C, \& Tandon, K. (1996). Foreign acquisitions in the United States: effect on shareholder wealth of foreign acquiring firm. Journal of Banking and Finance 20, 307-329.

Caves, R. E. (1971). International corporations: The industrial economics of foreign investment. Econom-ica 38, 1-28.

Comment, R., \& Jarrell, G. (1987). Two-tier and negotiated tender offers: the imprisonment of the freeriding shareholder. Journal of Financial Economics 19, 283-310.

Conn, R. L., \& Connell, F. (1990). International mergers: returns to U.S. and British firms. Journal of Business Finance and Accounting 17, 689-711.

Datta, D. K., \& Puia, G. (1995). Cross-border acquisitions: an examination of the influence of related and cultural fit on shareholder value creation in U.S. acquiring firms. Management International Review 35, 337-359.

Doukas., J. (1995). Overinvestment, Tobin's q and Gainds from foreign acquisitions. Journal of Banking and Finance 19, 1285-1303.

Doukas, J., \& Travlos, N. G. (1988). The effect of corporate multinationalism on shareholders' wealth: evidence from international acquisitions. Journal of Finance 43, 1161-1175.

Errunza, V. (1977). Gains from portfolio diversification into less-developed countries's securities. 
Published in : International review of financial analysis(2000), vol. 9, iss. 2, pp. 163-174

Status : Postprint (Author's version)

Journal of International Business Studies, 83-99.

Errunza, V., \& Senbet, L. W. (1981). The effects of international operations on the market value of the firm: theory and evidence. Journal of Finance 36, 401-418.

Fatemi, A., \& Furtado,E. P.(1988). An empirical investigationofthe wealth effects of foreign acquisitions.In S. Kouri \& A. Ghosh (Eds.), Recent Developments in International Banking and Finance (Vol. 2, pp. 363-379).

Lexington, MA: Lexington Books. Froot, K. A., \& Stein, J. C. (1989). Exchange rates and foreign direct investment. NBER working paper, 2914.

Grey, R., \& Thorne, T. (1990). Differences between North American and European corporate cultures. Canadian Business Review 10, 26-30.

Hill, C., Hwang, P., \& Kim, W. C. (1991). An eclectic theory of the choice of international entry mode. Strategic Management Journal 11, 117-128.

Hymer, S. (1976). The International Operation of National Firms: A Study of Direct Foreign Investment. Cambridge, MA: MIT Press.

Kang, J. K. (1993). The international market for corporate control. Journal of Financial Economics 33, 345-371.

Lessard, D. R. (1976). World, country, and industry relationships in equity returns: implications for risk reduction through international diversification. Financial Analysts Journal 32, 32-38.

Lougue, D. E. (1982). An experiment in international diversification. Journal of Portfolio Management 9, 22-27.

Markides, C. C., \& Ittner, C. D. (1994). Shareholder benefits from corporate international diversification: evidence from U.S. international acquisitions. Journal of International Business Studies $25,343-366$

Prowse, S. (1995). Corporate governance in an international perspective: a survey of corporate control mechanisms among large firms in the US, UK, Japan, and Germany. Financial Markets, Institutions \& Instruments 4(1), 1-63. 